\title{
The Impact of Precarious Work on Going to Work Sick and Sending Children to School Sick During the COVID-19 Pan- demic
}

\author{
Mindy Shoss ${ }^{1, *}$, Hanyi Min ${ }^{1}$, Kristin Horan ${ }^{1}$, Ann Schlotzhauer ${ }^{1}$, Jeannie Nigam ${ }^{2}$, Naomi Swanson ${ }^{3}$ \\ 1 University of Central Florida \& Australian Catholic University; Postal Address: Department of Psychol-ogy, \\ University of Central Florida, PO Box 161390, Orlando, FL 32816-1390, USA; hanyi.min@ucf.edu (H.M.); \\ kristin.horan@ucf.edu (K.H.); aeschlotz@knights.ucf.edu (A.S.); \\ 2 National Institute for Occupational Safety and Health, Centers for Disease Control \& Prevention. 1090 Tus- \\ culum Avenue, Cincinnati, OH 45226, USA; zgy1@cdc.gov \\ 3 National Institute for Occupational Safety and Health, Centers for Disease Control \& Prevention. 1090 Tus- \\ culum Avenue, Cincinnati, OH 45226, USA; nws3@cdc.gov \\ * Correspondence: mindy.shoss@ucf.edu
}

Publisher's Note: MDPI stays neutral with regard to jurisdictional claims in published maps and institutional affiliations.

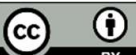

Copyright: @ 2021 by the authors. Submitted for possible open access publication under the terms and conditions of the Creative Commons Attribution (CC BY) license (http://creativecommons.org/licenses/by/4.0/).

\begin{abstract}
Precarious work captures the structural, financial, and social conditions that make work uncertain/unstable and workers vulnerable to mistreatment at work. Building on the idea that precarious work limits agency and engenders fear, we examined whether precarious workers were more likely to attend work while ill in general and, more specifically, while having the COVID-19 virus (i.e., presenteeism). We also examined whether precarious work is a risk factor for sending children to daycare/school while ill. In a multi-wave prospective study in the United States, we surveyed 300 employees working fully on-site (i.e., in person) during the COVID-19 pandemic. At each survey wave, 5-7\% reported going to work with a confirmed/possible COVID case, $9-10 \%$ reported going to work despite a close contact with a confirmed/possible COVID case, and 11-15\% reported sending a child to school or daycare sick. Multiple regression results revealed that worker vulnerability at Wave 1 (August 27-September 4, 2020) significantly predicted three types sickness presenteeism over the subsequent three weeks (measured by number of days): general presenteeism (going to work sick), presenteeism with confirmed or suspected case of COVID, and going to work when a contact had a case of COVID. Affective job insecurity significantly predicted secondary presenteeism, specifically sending a sick child to school or daycare. Our results further revealed that personal benefit from the organization's COVID policies significantly moderated the relation between affective job insecurity and secondary presenteeism. These findings suggest that precarious work is a risk factor to virus spread.
\end{abstract}

Keywords: COVID-19 pandemic; presenteeism; precarious work

\section{Introduction}

The COVID-19 pandemic has disrupted nearly every aspect of life [1,2]. At the same time that the COVID-19 virus has threatened health, the pandemic has left many workers in vulnerable employment situations. A major concern raised regarding the pandemic's economic effects is the rise in precarious work, capturing the structural, financial, and social vulnerabilities faced by workers $[3,4]$. The current research examines the impact of precarious work conditions on in-person workers' decisions to attend work while ill during the pandemic and to send their children to daycare/school while ill.

We anticipated that precarious conditions, such as job insecurity, financial insecurity, worker ability to exercise rights (e.g., take sick leave), and vulnerability (i.e., feeling defenseless to authoritarian work conditions) create conditions where individuals are fearful of being absent from work [5] and feel that they have no other option but to attend work 
sick or send their children to daycare/school while ill [6]. Additionally, because employers play a critical role in crafting environments that are conducive to desired attendance and safety behavior, as highlighted in the CDC's Interim Guidance for Businesses and Employers Responding to Coronavirus Disease 2019 [7], it is possible that employer policies (e.g., paid sick leave) may mitigate some of these effects. Such an investigation is of practical importance given that public health officials warn that changing individual behavior is crucial for minimizing virus spread. Our investigation also addresses methodological and conceptual challenges in presenteeism research [8], and advances the field's understanding of individual health-related behavior during a pandemic $[9,10]$.

\section{Methods}

Using the ROI Rocket Survey firm, we recruited a sample of 303 individuals working full-time in-person at a work site. The sample is mostly female $(74.75 \%)$ and Caucasian (83.67\%). Other ethnicities represented are American Indian or Alaskan Native (1.67\%), Asian or Pacific Islander (2.67\%), Black or African American (6.00\%), Hispanic or Latinx $(5.00 \%)$, and Other $(1.00 \%)$. Wave 1 of data collection took place between August 27 and September 4, 2020; and Wave 2 was distributed 3 weeks later. A total of 210 participants responded to the Wave 2 survey. The largest portion of the sample (27.24\%) reported working in health care or social assistance, $8.97 \%$ work in retail trade, $7.31 \%$ in education, and the remainder in other industries. Participants who only responded to the Wave 1 survey are significantly younger than those who participated in both surveys $(\mathrm{t}=2.91$, $\mathrm{p}=.004)$, but these two groups did not significantly differ in gender $(\mathrm{t}=-.25, \mathrm{p}=.80)$. Thus, we included age as a control.

Participants responded to questionnaires at both waves, including Hellgren et al.'s (1999) job insecurity (e.g., "I feel uneasy about losing my job in the near future"), Muyon et al.'s (2019) financial insecurity (e.g., "I have financial stability" reverse coded), Vives et al.'s (2015) vulnerability (e.g., please indicate the frequency with which each of the following occurs... You are able to request better working conditions without being exposed to retaliation?, reverse coded) and exercise rights (e.g., please indicate how often you are able to do the following without obstacles from your work...Take sick leave when you need to) [11-13].

Regarding presenteeism, we asked participants the item from Johns (2011), "How many days in the past 3 weeks (including today) did you go to work even though you were sick or not feeling well?" and allowed participants to indicate from 0-21 days [14]. We adapted this item to create COVID-19 specific measures: "Did you go to work at any point over the past 3 weeks after someone with whom you have had contact had a confirmed or possible case of COVID-19?" "Did you go to work at any point over the past 3 weeks even though you had a possible or confirmed case of COVID-19?" For participants who reported responsibilities for children under the age of 18, we asked "Did one or more of the children living in your home attend daycare or school even though they had any of the following symptoms? (0 days-21 days) Fever or chills, Cough, Shortness of breath or difficulty breathing, Fatigue, Muscle or body aches, Headache, New loss of taste or smell, Sore throat, Congestion or runny nose, Nausea or vomiting, Diarrhea." Finally, participants were asked to select which COVID-19-related policies their employer put in place (e.g., waived attendance policy for some or all employees; engineered the workplace for infection prevention; provided funds to help pay for the cost of medical check-ups) $[15,16]$ and the extent to which they personally benefited from each policy.

\section{Results and Discussion}

At each survey wave, 5-7\% reported going to work with a confirmed/possible COVID case during the previous three weeks, 9-10\% reported going to work despite a close contact with a confirmed/possible COVID case, and 11-15\% reported sending a child to school or daycare sick. CFA results from nested model comparisons indicated that the model 
with the items for the precarious work constructs loaded on their own correspondent latent factor fits the data best, supporting that the examined constructs are distinct from each other $(\mathrm{X} 2(\mathrm{df}=1313.05), \mathrm{CFI}=.93, \mathrm{SRMR}=.06, \mathrm{RMSEA}=.051)$.

When four elements of precarious work (financial insecurity, affective job insecurity, vulnerability, and ability to exercise rights) and age were included together as a predictors in a multiple regression equation, worker vulnerability at Time 1 significantly predicted three sickness presenteeism variables at Time 2: general presenteeism (going to work sick; $b=1.63$, se $=.56, p<.01)$, presenteeism with confirmed or suspected case of COVID $(b=$ $.94, s e=.38, p<.05)$, and presenteeism when a contact had a case of COVID $(b=1.21$, se $=$ $.50, p<.05)$. In each case, more vulnerable workers were more likely to attend work while ill over the subsequent weeks. None of the other variables were significant. Job insecurity at Time 1 significantly predicted secondary presenteeism (i.e., sending a sick child to school or daycare) at Time $2(b=1.04, s e=.38, p<.01)$. Those who were more insecure about their jobs were more likely to send their child to school or daycare while ill over the next few weeks. Finally, our results revealed that personal benefit from the organization's COVID policies significantly moderated the relation between job insecurity and secondary presenteeism (job insecurity $b=3.05$, $s e=.87, \mathrm{p}<.001$; personal benefit $\mathrm{b}=.70$, se $=.60, \mathrm{p}$ $=.25$; interaction $b=-0.53$, se $=.25, p=.033$ ). As the graph below demonstrates, the relationship between affective job insecurity and secondary presenteeism was mitigated to the extent to which the organization provided beneficial policies to enable employees to better cope with the pandemic. None of the other moderating effects were significant.

\subsection{Table 1}

\begin{tabular}{ccccc}
\hline $\begin{array}{c}\text { Precarious Work } \\
\text { Predictors (Time } \\
\mathbf{1})\end{array}$ & $\begin{array}{c}\text { Time 2 Presen- } \\
\text { teeism General } \\
\mathbf{b}(\mathbf{s e})\end{array}$ & $\begin{array}{c}\text { Time 2 Presentee- } \\
\text { ism COVID19 } \\
\text { b(se) }\end{array}$ & $\begin{array}{c}\text { Time 2 Presen- } \\
\text { teeism Contact } \\
\text { COVID19 b(se) }\end{array}$ & $\begin{array}{c}\text { Time 2 Second- } \\
\text { ary } \\
\text { Presenteeism } \\
\text { b(se) }\end{array}$ \\
\hline Financial Security & $-.41(.30)$ & $.09(.20)$ & $-.07(.27)$ & $-.16(.25)$ \\
Job Insecurity &.$- .48(.35)$ & $-.38(.24)$ & $-.26(.32)$ & $\mathbf{1 . 0 4}(. \mathbf{3 8})^{* *}$ \\
Vulnerability & $\mathbf{1 . 6 3 ( . 5 6 ) ^ { * * }}$ & $\mathbf{. 9 4 ( . 3 8 ) ^ { * }}$ & $\mathbf{1 . 2 1}(\mathbf{. 5 0})^{*}$ & $-.07(.55)$ \\
$\begin{array}{c}\text { Ability to Exercise } \\
\text { Rights }\end{array}$ & $-.28(.31)$ & $.01(.21)$ & $.10(.28)$ & $.01(.28)$ \\
Age & $.02(.04)$ & $.03(.03)$ & $-.03(.04)$ & $.01(.05)$ \\
$\mathrm{R}^{2}$ & .08 & .04 & .04 & .17 \\
\hline
\end{tabular}

Table 1. Multiple regression results predicting Time 2 presenteeism variables from Time 1 precarious work. ${ }^{*} p<.05 ;{ }^{* *} p<.01$.

\subsection{Figure 1}

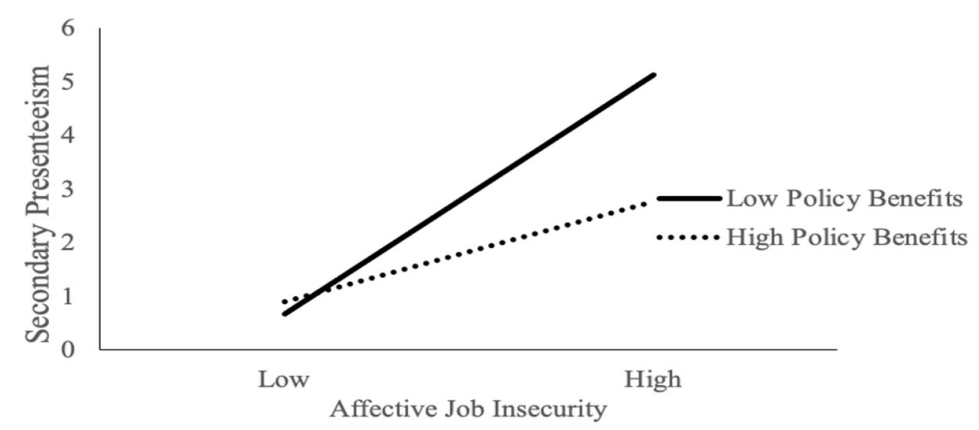

Figure 1. Interaction between affective job insecurity and employer policy benefits predicting secondary presenteeism (days sent child to school or daycare sick). 


\section{Conclusions}

Precarious work conditions, particularly worker vulnerability and job insecurity, appear to be risk factors for virus spread by enhancing the likelihood that people attend work or send their children to school/daycare while ill. The latter effect is mitigated by employer support. This suggests that safety net mechanisms at the organization level may serve to minimize some risk, at least to the extent to which they address the needs of workers.

The Occupational Safety and Health Administration (OSHA) emphasizes the importance of administrative controls such as encouraging sick workers to stay home, implementing telework or alternating schedules, and communicating the availability of worker health resources [16]. Given the findings regarding vulnerability, employers must not only institute relevant policies, but also ensure that employees feel empowered to make use of them. Vulnerability can also be reduced by minimizing exposures to workplace hazards, implementing safe policies and procedures, fostering awareness of workplace safety and health, and empowering workers [17].

In summary, the workplace and worker behavior play an important role in mitigating virus spread. In this vein, precarious work conditions, especially vulnerability and job insecurity, not only reflect threats to individual employees' livelihood but also reflect threats to the health and well-being of the broader community in which workplaces are embedded.

Acknowledgments: This research was funded by National Institute for Occupational Safety and Health contract \#9278082.

\section{References}

1. Kalleberg, A.L. Precarious work, insecure workers: Employment relations in transition. American Sociological Review, 2009, 74, 1-22.

2. Rudolph, C.W.; Allan, B.; Clark, M.; Hertel, G.; Hirschi, A.; Kunze, F.; Shockley, K.; Shoss, M.; Sonnentag, S.; Zacher, H. Pandemics: Implications for Research and Practice in Industrial and Organizational Psychology. Industrial and Organizational Psychology: Perspectives on Research and Practice, advance online publication.

3. Benach, J.; Vives, A.; Amable, M.; Vanroelen, C.; Tarafa, G.; Muntaner, C. Precarious employment: Understanding an emerging social determinant of health. Annual Review of Public Health, 2014, 35, 229-253.

4. Virtanen, M.; Kivimäki, M.; Elovaino, M.; Vahtera, J.; Ferrie; J.E. From insecure to secure employment: changes in work, health, health related behaviours, and sickness absence. Occupational and Environmental Medicine, 2003, 60, 948-953.

5. Kalleberg, A.L.; Marsden, P.V. Changing work values in the United States, 1973-2006. Social Science Research, 2013, 42, 255-270.

6. Centers for Disease Control and Prevention. Steps to take if you are sick. 2020. https://www.cdc.gov/coronavirus/2019-ncov/if-you-aresick/steps-when-sick.html

7. Centers for Disease Control and Prevention. Interim guidance for business and employers responding to coronavirus disease 2019 (COVID19). 2020. https://www.cdc.gov/coronavirus/2019-ncov/community/guidance-business-response.html

8. Johns, G. Presenteeism in the workplace: A review and research agenda. Journal of Organizational Behavior, 2010, 31, 519-542.

9. Blake, K.D.; Blendon, R.J.; Viswanath, K. Employment and compliance with pandemic influenza mitigation recommendations. Emerging Infectious Diseases, 2010, 16, 212-218.

10. Probst, T.M.; Lee, H.J.; Bazzoli, A. Economic stressors and the enactment of CDC-recommended COVID-19 prevention behaviors: The impact of state-level context. Journal of Applied Psychology, advance online publication.

11. Hellgren, J.; Sverke, M; Isaksson, K. A two-dimensional approach to job insecurity: Consequences for employee attitudes and well-being. European Journal of Work and Organizational Psychology, 1999, 8, 179-195.

12. Munyon, T.P.; Carnes, A.M.; Lyons, L.M.; Zettler, I. All about the money? Exploring antecedents and consequences for a brief measure of perceived financial security. Journal of Occupational Health Psychology, 2020, 25, 159-175.

13. Vives, A.; González, F.; Moncada, S.; Llorens, C.; Benach, J. Measuring precarious employment in times of crisis: the revised Employment Precariousness Scale (EPRES) in Spain. Gaceta Sanitaria, 2015, 29, 379-382.

14. Johns, G. Attendance dynamics at work: the antecedents and correlates of presenteeism, absenteeism, and productivity loss. Journal of Occupational Health Psychology, 2011, 483-500.

15. Jiang, I. From Walmart to Starbucks, these 22 retail companies are changing their benefits policies amid the coronavirus pandemic. Business Insider, 2020. https://www.businessinsider.com/coronavirus-changes-walmart-starbucks-employee-benefits-2020-3

16. U.S. Department of Labor Occupational Safety and Health Administration. Guidelines on preparing workplaces for COVID-19. 2020. https://www.osha.gov/Publications/OSHA3990.pdf

17. Smith, P.M.; Saunders, R.; Lifshen, M,; Black, O.; Lay, M.; Breslin, F. C.; ... \& Tompa, E. The development of a conceptual model and selfreported measure of occupational health and safety vulnerability. Accident Analysis \& Prevention, 2015, 82, 234-243. 